\title{
Methylobacterium, a major component of the culturable bacterial endophyte community of wild Brassica seed
}

\author{
Davood Roodi ${ }^{1,2,3}{ }^{\text {, James P Millner }}{ }^{1}$, Craig McGill ${ }^{1}$, Richard D Johnson ${ }^{3}$, Ruy Jauregui ${ }^{4}$, Stuart D Card ${ }^{\text {Corresp. } 3}$ \\ ${ }^{1}$ School of Agriculture \& Environment, Massey University, Palmerston North, Manwatu, New Zealand \\ Agricultural Research, Education and Extension Organization (AREEO), Seed and Plant Improvement Institute, Karaj, Alborz, Iran \\ 3 Forage Science, AgResearch Limited, Grasslands Research Centre, Palmerston North, Manawatu, New Zealand \\ 4 Knowledge \& Analytics, AgResearch Limited, Grasslands Research Centre, Palmerston North, Manawatu, New Zealand \\ Corresponding Author: Stuart D Card \\ Email address: Stuart.Card@agresearch.co.nz
}

Background. Plants are commonly colonized by a wide diversity of microbial species and the relationships created can range from mutualistic through to parasitic. Microorganisms that typically form symptomless associations with internal plant tissues are termed endophytes. Endophytes associate with most plant species found in natural and managed ecosystems. They are extremely important plant partners that provide improved stress tolerance to the host compared with plants that lack this symbiosis. Plant domestication has reduced endophyte diversity and therefore the wild relatives of many crop species remain untapped reservoirs of beneficial microbes. Brassica species display immense diversity and consequently provide the greatest assortment of products used by humans from a single plant genus important for agriculture, horticulture, bioremediation, medicine, soil conditioners, composting crops, and in the production of edible and industrial oils. Many endophytes are horizontally transmitted, but some can colonize the plant's reproductive tissues, and this gives these symbionts an efficient mechanism of propagation via plant seed (termed vertical transmission).

Methods. This study surveyed 83 wild and landrace Brassica accessions composed of 14 different species with a worldwide distribution for seed-originating bacterial endophytes. Seed was stringently disinfected, sown within sterile tissue culture pots within a sterile environment and incubated. After approximately one-month, direct isolation techniques were used to recover bacterial endophytes from roots and shoots of symptomless plants. Bacteria were identified based on the PCR amplification of partial 16S rDNA gene sequences and annotated using the BLASTn program against the NCBI rRNA database. A diversity index was used as a quantitative measure to reflect how many different bacterial species there were in the seed-originating microbial community of the Brassica accessions sampled.

Results. Bacterial endophytes were recovered from the majority of the Brassica accessions screened. 16S rDNA gene sequencing identified 19 different bacterial species belonging to three phyla, namely Actinobacteria, Firmicutes and Proteobacteria with the most frequently isolated species being Methylobacterium fujisawaense, Stenotrophomonas rhizophila and Pseudomonas lactis. Methylobacterium was the dominant genus composing $56 \%$ of the culturable isolated bacterial community and was common in $77 \%$ of accessions possessing culturable bacterial endophytes. Two selected isolates of Methylobacterium significantly promoted plant growth when inoculated into a cultivar of oilseed rape and inhibited the growth of the pathogen Leptosphaeria maculans in dual culture. This is the first report that investigates the seed-originating endophytic microorganisms of wild Brassica species and highlights the Brassica microbiome as a resource for plant growth promoting bacteria and biological control agents.

PeerJ reviewing PDF | (2020:02:46010:1:1:NEW 8 Jun 2020) 


\section{Methylobacterium, a major component of the}

2 culturable bacterial endophyte community of wild

3 Brassica seed

4

5

6

7

8

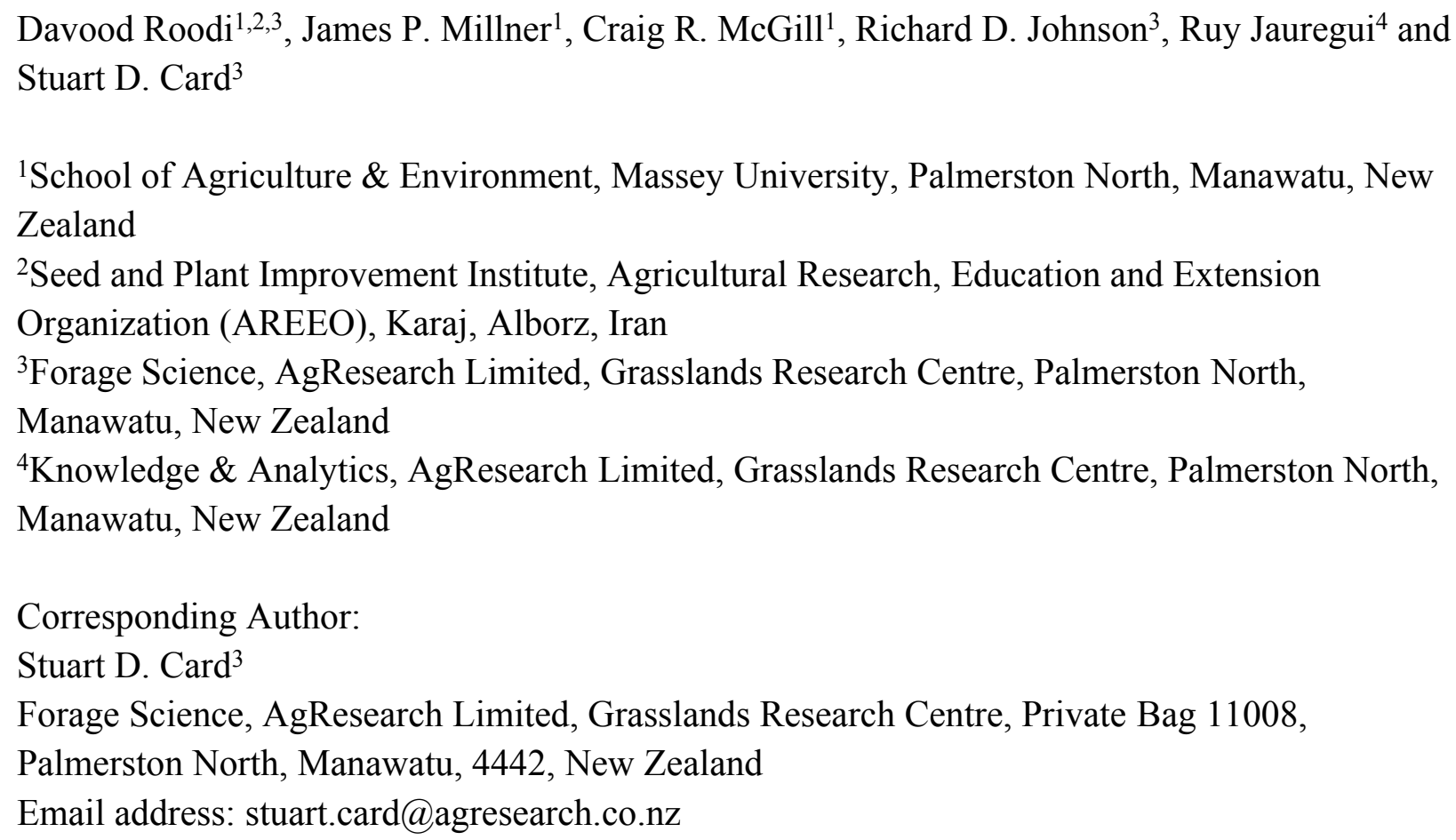

\section{Abstract}

Background. Plants are commonly colonized by a wide diversity of microbial species and the relationships created can range from mutualistic through to parasitic. Microorganisms that typically form symptomless associations with internal plant tissues are termed endophytes. Endophytes associate with most plant species found in natural and managed ecosystems. They are extremely important plant partners that provide improved stress tolerance to the host compared with plants that lack this symbiosis. Plant domestication has reduced endophyte diversity and therefore the wild relatives of many crop species remain untapped reservoirs of beneficial microbes. Brassica species display enormous diversity and subsequently provide the widest assortment of products used by man from a single plant genus important for agriculture, horticulture, bioremediation, medicine, soil conditioners, composting crops, and in the production of edible and industrial oils. Many endophytes are horizontally transmitted, but some can colonize the plant's reproductive tissues, and this gives these symbionts an efficient mechanism of propagation via plant seed (termed vertical transmission).

Methods. This study surveyed 83 wild and landrace Brassica accessions composed of 14 different species with a worldwide distribution for seed-originating bacterial endophytes. Seed 
40 was stringently disinfected, sown within sterile tissue culture pots within a sterile environment

41

42

43

44

45

46

47

48

49

50

51

52

53

54

55

56

57

58

59

60

61

62

63

64

65

66

67

68

69

70

71

72

73

74

75

76

77

78

79

and incubated. After approximately one-month, direct isolation techniques were used to recover bacterial endophytes from roots and shoots of symptomless plants. Bacteria were identified based on the PCR amplification of partial 16S rDNA gene sequences and annotated using the BLASTn program against the NCBI rRNA database. A diversity index was used as a quantitative measure to reflect how many different bacterial species there were in the seed-originating microbial community of the Brassica accessions sampled.

Results. Bacterial endophytes were recovered from the majority of the Brassica accessions screened. 16S rDNA gene sequencing identified 19 different bacterial species belonging to three phyla, namely Actinobacteria, Firmicutes and Proteobacteria with the most frequently isolated species being Methylobacterium fujisawaense, Stenotrophomonas rhizophila and Pseudomonas lactis. Methylobacterium was the dominant genus composing $56 \%$ of the culturable isolated bacterial community and was common in $77 \%$ of accessions possessing culturable bacterial endophytes. Two selected isolates of Methylobacterium significantly promoted plant growth when inoculated into a cultivar of oilseed rape and inhibited the growth of the pathogen Leptosphaeria maculans in dual culture. This is the first report that investigates the seedoriginating endophytic microorganisms of wild Brassica species and highlights the Brassica microbiome as a resource for plant growth promoting bacteria and biological control agents.

\section{Introduction}

Endophytes are a diverse sub-group of microorganisms that reside inside the tissues of nearly every vascular plant and, for at least part of their life cycle, do not cause any immediate symptoms (Card et al. 2016; Hardoim et al. 2015; Porras-Alfaro \& Bayman 2011; Wilson 1995). However, not all endophytes remain within their plant host throughout their entire life cycle. Additionally, some may change their behavior, from mutualistic to commensalism or even pathogenic, due to a change in the environment, during host senescence or when the host is stressed (Aly et al. 2011; Fisher \& Petrini 1992). Endophytes can be found in nearly every type of plant organ, in both vegetative (e.g. leaves, roots and shoots) and reproductive (e.g. flower and seed) tissues (Rodriguez et al. 2009). The presence of bacterial endophytes within the reproductive tissues has been reported for many plant species (Mundt \& Hinkle 1976), including coffee (Vega et al. 2005), cotton (Adams \& Kloepper 1996), cucumber (Khalaf \& Raizada 2016), eucalyptus (Ferreira et al. 2008), oilseed rape (Granér et al. 2003), maize (Rijavec et al. 2007), Norway spruce (Cankar et al. 2005), tobacco (Mastretta et al. 2009) and rice (Elbeltagy et al. 2000; Okunishi et al. 2005). These seed-originating bacterial endophytes may be disseminated from one generation to the next, persisting in the next population of plants (López-López et al. 2010) and is indicative of their ability to vertically transmit. Plant hosts harboring endophytes can gain additional advantageous traits, granting them an ecological advantage over individuals lacking these microorganisms and/or other plant species that occupy a similar ecological niche. These benefits include greater resistance to abiotic and biotic stresses (Hallmann et al. 1997; Mastretta et al. 2006) as well as plant growth promotion (Azevedo et al. 2000).

Peer) reviewing PDF | (2020:02:46010:1:1:NEW 8 Jun 2020) 
80

81

82

83

84

85

86

87

88

89

90

91

92

93

94

95

96

97

98

99

100

101

102

103

104

105

106

107

108

109

110

111

112

113

114

115

116

117

118

119

Modern Brassica cultivars were originally domesticated from species mostly originating from Europe (Rakow 2004), although now many Brassica crops, particularly Brassica napus (oilseed rape), Brassica rapa (turnip) and Brassica oleracea (cabbage), are extensively cultivated throughout the world. These species are a major source of vegetables for human consumption and for forage, ornamental plants, condiments, medicinal crops, green manure, bioremediation, and as very important sources of edible and industrial oils (Dixon 2007; Gómez-Campo 1980). A wide range of insect pests, such as aphids (Brevicoryne brassica), diamond back moth (Plutella xylostella) and flea beetles (Phyllotreta and Psylliodes spp.), in addition to several diseases, such as clubroot (caused by Plasmodiophora brassicae), phoma stem canker (caused by Leptosphaeria maculans), and sclerotinia stem rot (caused by Sclerotinia sclerotiorum) cause extensive damage to Brassica crops worldwide (Kimber \& McGregor 1995) with few or no control options available (Granér et al. 2003).

Most studies investigating endophytes of Brassica have focused on isolating microorganisms from the vegetative tissues of modern-day cultivars (Germida et al. 1998; Narisawa et al. 1998; Sheng et al. 2008; Sunkar \& Nachiyar 2013; Zhang et al. 2014). However, this strategy may be restrictive as the diversity and frequency of endophytic species found in domesticated crops is assumed to be much lower than in their respective wild relatives (Mousa et al. 2015; Putra et al. 2015). Additionally, targeting endophytic species that are associated with the reproductive plant tissues (those microorganisms that are seed-borne or seed-transmitted) would greatly aid the marketing of potential commercial products (Card et al. 2016; Card et al. 2015). This study focused on developing a strategy for screening wild and landrace Brassica species for mutualistic, seed-originating endophytes that may offer beneficial traits to elite Brassica cultivars.

\section{Materials \& Methods}

\section{Brassica germplasm}

Sixty-four accessions (49 wild and 15 landraces) of Brassica (Table S1), encompassing a diverse number of species, with a worldwide distribution, were obtained from three international genebanks, namely The United States Department of Agriculture (USDA) via The Germplasm Resources Information Network (GRIN), The Leibniz-Institute of Plant Genetics and Crop Plant Research (IPK Gatersleben) and The Nordic Genetic Resource Centre (NordGen). These accessions were imported into the Margot Forde Germplasm Centre (MFGC), New Zealand's national genebank of grassland plants (on seed import permit no. 2015058982). A further 19 populations of wild Brassica were collected locally, within the Manawatu-Wanganui region situated in the lower half of the North Island of New Zealand. All 83 accessions were catalogued and stored at $0^{\circ} \mathrm{C}$ and $30 \%$ relative humidity within the MFGC.

Peer) reviewing PDF | (2020:02:46010:1:1:NEW 8 Jun 2020) 
120 Screening for seed-originating bacterial endophytes

121 Two surface disinfection protocols were developed to remove non-target microorganisms (such

122 as saprophytic microorganisms) associated with the seed surface of the aforementioned Brassica

123 accessions. Initially all 83 accessions were surface disinfected using the following protocol:

124 seeds were washed for five min in 5\% aqueous Tween- $20{ }^{\circledR}$ solution (Sigma-Aldrich Inc., New

125 Zealand), two min in 70\% ethanol, $10 \mathrm{~min}$ in $0.5 \%$ sodium hypochlorite, one min in $70 \%$ ethanol

126 and rinsed three times in sterile water. To assess the efficacy of the surface disinfection

127 protocols, $3 \times 20 \mu \mathrm{L}$ drops of tap water from the last rinse were plated onto nutrient agar (NA),

128 (CM003, Oxoid Ltd., UK). Petri plates containing the NA were incubated for two weeks at $22^{\circ} \mathrm{C}$

129 and inspected daily for microbial growth with the aid of a dissecting microscope (Carl Zeiss

130 (N.Z.) Ltd., New Zealand). For those accessions where saprophytic microorganisms were

131 initially observed, a second surface disinfection protocol was applied whereby the same

132 procedure listed above was repeated except for one modification; seeds were immersed for 10

$133 \mathrm{~min}$ in $2 \%$ sodium hypochlorite rather than a $0.5 \%$ solution. Seed were then dried on filter paper

134 (110 mm, Thermo Fisher Scientific Ltd., New Zealand) within a sterile environment and stored

135 at $4{ }^{\circ} \mathrm{C}$ in the dark. To induce germination, seeds were dipped into sterile $0.2 \% \mathrm{KNO}_{3}$ solution

136 and immediately plated onto Petri plates containing $1.5 \%$ water agar (WA), with 10 seeds per

137 plate. Petri plates were incubated at $4{ }^{\circ} \mathrm{C}$ in the dark for $72 \mathrm{~h}$ to break seed dormancy. Dormant

138 accessions (as tested for 15 accessions) resulted in either zero or poor germination without this

139 process and were subsequently transferred to a custom-built growth chamber at $22-25^{\circ} \mathrm{C}$ and a

140 16/8 h (light/dark) photoperiod.

141

142 Seed and the subsequent seedlings were examined daily under a dissecting microscope and those

143 exhibiting any obvious epiphytic microbial growth were discarded. After 2-3 days, 10 clean

144 seedlings, from each accession, were transferred to sterile tissue culture pots, $98 \mathrm{~mm}$ diameter

145 (2105646, Alto Ltd., New Zealand) containing Murashige \& Skoog (MS) basal salts (Murashige

146 \& Skoog 1962) with minimal organics (Sigma-Aldrich, New Zealand), plus 3\% sucrose and

147 1.5\% agar (Ali et al. 2007). Pots were placed in the growth chamber (with the same settings as

148 described earlier) and visually assessed every day for a month using a dissecting microscope.

149 Plants were discarded if they showed any disease symptoms or any saprophytic microbial

150 growth. Four clean seedlings were finally selected from each accession and subsequently

151 dissected into two components: shoot and root. These organs were further dissected into 2-3 $\mathrm{mm}^{2}$

152 pieces using sterile forceps and a scalpel. Ten pieces per organ type from each seedling were

153 transferred to Petri plates containing NA. Petri plates were incubated for three weeks at $22{ }^{\circ} \mathrm{C}$ in

154 the dark and checked daily under a dissecting microscope for microbial growth. Bacterial

155 colonies arising from dissected tissue pieces were selected, sub-cultured and checked for purity.

156 Representative bacterial isolates were then sub-cultured onto fresh NA using a sterile loop and

157 stored in $25 \%$ glycerol at $-80{ }^{\circ} \mathrm{C}$.

158

159 Identification of seed-originating bacterial endophytes

Peer) reviewing PDF | (2020:02:46010:1:1:NEW 8 Jun 2020) 
160 Bacterial isolates were identified based on the PCR amplification of partial 16S rDNA gene

161

162

163

164

165

166

167

168

169

170

171

172

173

174

175

176

177

178

179

180

181

182

183

184

185

186

187

188

189

190

191

192

193

194

195

196

197

198

199

sequences (Weisburg et al. 1991). PCR was performed directly on suspensions of each purified bacterial colony as follows: each colony was suspended in $10 \mu \mathrm{L}$ Milli-Q ${ }^{\circledR}$ water in a standard $0.2 \mathrm{~mL}$ PCR tube (Axygen ${ }^{\mathrm{TM}}$, USA) and frozen at $-20^{\circ} \mathrm{C}$ before being thawed and heated at $65^{\circ} \mathrm{C}$ for $30 \mathrm{~min} .1 \mu \mathrm{L}$ of suspension was added to the PCR reaction containing $5 \mu \mathrm{L} 10 \mathrm{X}$ PCR buffer, $1.5 \mu \mathrm{L} \mathrm{MgCl}_{2}(50 \mathrm{mM}$ ), forward primer, 27F (5 -AGAGTTTGATCCTGGCTCAG, $1 \mu \mathrm{L}, 10$ $\mu \mathrm{M}$ ), reverse primer R1497, (5` - CCTATATCGCCGGTAATT, $1 \mu \mathrm{L}, 10 \mu \mathrm{M}$ ), $0.4 \mu \mathrm{L}$ dNTPS (25 $\mathrm{mM}), 0.25 \mu \mathrm{L}$ Taq-polymerase and $39.85 \mu \mathrm{L}$ sterile Milli-Q water to make a $50 \mu \mathrm{L}$ PCR reaction. PCR was performed in a thermocycler (Bio-Rad C1000 Touch ${ }^{\mathrm{TM}}$, Bio-Rad Laboratories Inc., USA) with the following conditions: an initial step of $95^{\circ} \mathrm{C}$ for $5 \mathrm{~min}$ was followed by 36 cycles of $94{ }^{\circ} \mathrm{C}$ for $30 \mathrm{~s}, 56^{\circ} \mathrm{C}$ for $60 \mathrm{~s}, 72^{\circ} \mathrm{C}$ for $90 \mathrm{~s}$ and a final step of $72{ }^{\circ} \mathrm{C}$ for $10 \mathrm{~min}$; PCR amplification products were confirmed by electrophoresis in a $1.5 \%$ agarose gel and purified using the DNA clean \& concentrator kit (Zymo Research Corporation, USA) prior to Sanger sequencing (Sanger \& Coulson 1975) (New Zealand Genomics Ltd., New Zealand). The raw sequence ab1 files were imported into the software package Geneious Prime ${ }^{\circledR}$ version 2019.1.1 (Biomatters Ltd., New Zealand) and were quality trimmed using an error probability of 0.05 . Those sequences with a region of high quality greater or equal than $600 \mathrm{bp}$ were kept and annotated using the BLASTn program against the NCBI rRNA database. The sequences were aligned using the multiple alignment program MAFFT (Katoh \& Standley 2013), and a Maximum Likelihood phylogenetic tree was generated using the software Mega X (Kumar et al. 2018) using a general time reversible model and validated by 100 bootstrap cycles. All sequence data were deposited in GenBank under file SUB6483552: MN629046 - MN629135. Simpson`s diversity index (Simpson 1949) was used as a quantitative measure to reflect how many different bacterial species there were in the seed-originating microbial community of the Brassica accessions sampled.

\section{Assessing plant growth promotion}

Two isolates of Methylobacterium, namely Methylobacterium fujisawaense (isolate B82) and Methylobacterium phyllosphaerae (isolate B64), were selected due to their high tissue colonization rate in their original host plants. The bacteria were plated on NA and incubated for two weeks at $22{ }^{\circ} \mathrm{C}$. For each isolate, cells were scraped from the Petri plates using a loop and transferred to an aqueous Tween $-20^{\circledR}$ solution. Concentrations were adjusted to $10^{9}$ cells per $\mathrm{mL}$ using a haemocytometer. Oilseed rape, cv. King was selected as the novel host plant. Seeds were surface disinfected, as described earlier, and placed on a filter paper under a laminar flow cabinet to dry. They were then transferred to Petri plates containing $2 \% \mathrm{WA}$ and incubated at $22{ }^{\circ} \mathrm{C}$ in a custom-made lighting room with 18/6 h (light/dark photoperiod) to initiate germination. The root tip of each seedling was excised with a sterile scalpel, dipped into the prepared bacterial suspension and transplanted into sterile plastic pots $(7 \times 15 \mathrm{~cm})$ containing autoclaved potting mix (50\% fine bark, $12.5 \%$ compost and $25 \%$ pumice plus nutrient, gypsum and Agri-lime). Control seedlings, after excising the root, were dipped in sterile water containing one drop of

Peer) reviewing PDF | (2020:02:46010:1:1:NEW 8 Jun 2020) 
200 Tween- $20^{\circledR}$ per liter. Pots were watered equally, and lids placed on top. Pots were transferred to a 201 plant growth chamber (A1000, Conviron Asia Pacific Pty Ltd., Australia) set at $18{ }^{\circ} \mathrm{C}$ with a 16/8

$202 \mathrm{~h}$ (light/dark) photoperiod. The experiment was laid out in a completely randomized design with 203 eight replications. Each experimental unit comprised five pots/plants. After one month, plants 204 were removed, and all soil debris cleaned by washing under a water tap. Each plant was placed 205 on a filter paper for $8 \mathrm{~h}$ at room temperature $\left(20-25^{\circ} \mathrm{C}\right)$ to completely dry. The seedlings were 206 weighed and the mean weight of five plants in each experimental unit were used for analysis of

207 208

209

210

211

212

213

214

215

216

217

218

219

220

221

222

223

224

225

226

227

228

229

230

231

232

233

234

235

236

237

238

239 variance (ANOVA) using SPSS software (IBM ${ }^{\odot}$ SPSS $^{\odot}$ Statistics, version 24).

\section{Dual culture test}

The antifungal activity of a representative isolate of each bacterial species was assessed in vitro (dual culture) against the target pathogen, L. maculans. The L. maculans strain Lm145 utilized was a virulent pathogen of Brassica sp., previously isolated from a swede crop in New Zealand (Lob 2014). Bacterial endophytes, previously stored at $-80^{\circ} \mathrm{C}$, were thawed, streaked onto NA and incubated for two weeks at $22^{\circ} \mathrm{C}$. For each bacterial isolate a cell suspension $\left(10^{9}\right.$ cells per $\mathrm{mL}$ ) was prepared and $50 \mu \mathrm{L}$ streaked in a straight line across the center of a Petri plate. Control treatments were streaked with only sterile water mixed with one drop of Tween- $20^{\circledR}$ per liter. Petri plates were incubated for two weeks at $22{ }^{\circ} \mathrm{C}$ and then two mycelial plugs $(5 \mathrm{~mm}$ diameter) were taken from the actively growing region of a two-week old L. maculans culture and placed $25 \mathrm{~mm}$ from the edge of each Petri plate opposite each other; there were 10 replicate plates for each treatment. When the two fungal colonies placed on opposite sides had grown sufficiently to close the gap between them, the distance between the bacterial colony and the L. maculans colony was measured using a digital caliper (Mitutoyo Corporation, Japan). The inhibition zone was rated using a 5 point scaling system: 4 (very high), inhibition zone $>10 \mathrm{~mm} ; 3$ (high), imbibition zone 5-10 mm; 2 (medium), inhibition zone $<5 \mathrm{~mm}$; 1 (low), L. maculans growth stopped at the bacterial streak line; 0 (zero), no inhibition zone with L. maculans typically growing over the bacterial streak (Hammoudi et al. 2012).

\section{Results}

\section{Seed-originating bacterial isolates}

In total, 54 accessions (44 wild and 10 landrace), out of the total 83 accessions surface disinfected and sown, resulted in symptomless plants when germinated and subsequently grown on MS medium. The remaining 29 accessions all exhibited epiphytic fungal growth, with most colonies identified as Alternaria sp. These plants were all destroyed by autoclaving. After incubation, bacterial colonies were detected from 48 symptomless wild Brassica accessions (38 wild and 10 landrace). Six accessions did not result in any bacteria being isolated.

\section{Identification of seed-originating bacteria}

A sample of 90 bacterial isolates, representing the morphological diversity of all the observed bacterial colonies that developed from dissected Brassica tissue, were sequenced to determine 
240 their species identity. 16S rDNA gene sequencing identified 19 different bacterial species 241 belonging to three phyla, namely Actinobacteria, Firmicutes and Proteobacteria (Fig. 1 and

242 Table 1). According to the phylogenetic tree (Fig. 1) the most frequently isolated species were

243 Methylobacterium fujisawaense (50 isolates), Stenotrophomonas rhizophila (10 isolates) and

244 Pseudomonas lactis (9 isolates). Three species were identified from the Actinobacteria, namely

245 Kocuria palustris, Micrococcus aloeverae, and Plantibacter flavus while two species were

246 identified from the Firmicutes phylum, namely Bacillus mycoides and Paenibacillus hordei.

247 Simpson's diversity index recorded a value of 0.74 indicating that these wild and landrace

248 Brassica accessions contained a high diversity of seed-originating bacteria. Nevertheless,

249 Methylobacterium spp., predominantly Methylobacterium fujisawaense and the closely related

250 species Methylobacterium phyllosphaerae, Methylobacterium oryzae and Methylorubrum

251 extorquens constituted $56 \%$ of the bacteria isolated and were common in $77 \%$ of the Brassica

252 accessions screened (38 accessions: 28 wild and 10 landrace). These were also distributed among

253 multiple Brassica species including Brassica barrelieri, Brassica elongate, Brassica gravinae,

254 Brassica indica, Brassica juncea, Brassica napus, Brassica nigra and Brassica rapa sourced

255 from five continents, namely Africa, Asia, Australasia, Europe and North America.

256

257

\section{Plant growth promotion}

258 Oilseed rape plants that were inoculated with two isolates of Methylobacterium showed a 259 significant $(\mathrm{P}<0.01)$ increase in their fresh weight when compared to the un-inoculated control 260 plants (Fig. 2). Plants inoculated with Methylobacterium fujisawaense (B82) had a mean weight

261

262

263

264

265

266

267

268

269

270

271

272

273

274

\section{Discussion}

276 This study investigated the cultivable bacterial community persisting in wild and landrace

277 Brassica seed. Nineteen bacterial species were isolated from 83 accessions, belonging to eight

278 Brassica species, covering five continents, with some of the accessions more than 20 years old.

279 The bacterial genera to which these species belong have been previously reported in the literature 
280

281

282

283

284

285

286

287

288

289

290

291

292

293

294

295

296

297

298

299

300

301

302

303

304

305

306

307

308

309

310

311

312

313

314

315

316

317

318

319

as seed endophytes of a diverse number of plant species. For example, Methylobacterium and Paenibacillus spp. have both been described as seed endophytes from Eucalyptus (Ferreira et al. 2008), Oryza sativa (Mano et al. 2006) and Phaseolus vulgaris (López-López et al. 2010), while Bacillus and Micrococcus spp. are common seed endophytes of Coffea arabica (Vega et al. 2005) and O. sativa (Mano et al. 2006). Our results indicate that the diversity of bacterial endophytes in seed of wild Brassica is relatively high with most of the bacterial species identified belonging to the Proteobacteria, the major phylum of gram-negative bacteria. This is consistent with earlier work that showed the seed microbiome of oilseed rape were colonized mostly by Proteobacteria and that individual cultivars each had their own unique microbiome profile (Rybakova et al. 2017).

Development of an effective surface disinfection protocol was paramount to this study. A protocol that was too harsh could sterilize the seed and kill any potentially beneficial microorganisms residing in the seed tissues, as well as potentially damaging the seed itself, while a protocol that was too moderate could yield unwanted saprophytic microorganisms residing on the surface of the seed coat. These non-target saprophytes have the potential to outgrow any slower growing endophytic organisms that may be beneficial. Many of these non-target species can colonize the interior tissues of the germinating plant during the emergence of the radicle (Bent \& Chanway 2002). The surface disinfection protocol used in this study was not designed to eliminate all organisms living on the seed surface, just to reduce their frequency. For example, Alternaria sp., commonly associated with seed coats or pericarps of seed (Harman 1983; Neergaard 2011) was frequently isolated.

Many studies have reported that strains belonging to the same genera identified in our study confer several beneficial traits to their host plants, including enhanced resistance against certain plant pathogens and/or growth promotion (Araújo et al. 2002; Berg \& Hallmann 2006; Khan et al. 2014; Rashid et al. 2012; Rout \& Chrzanowski 2009; Sessitsch et al. 2004; Ying et al. 2016). We assessed the antagonistic activity of selected isolates of bacterial species against $L$. maculans (the causal agents of phoma stem canker in oilseed rape) through dual culture bioassays and observed that Methylobacterium fujisawaense and Methylobacterium phyllosphaerae possessed antagonistic potential against the pathogen. The genus Methylobacterium is composed of pinkpigmented facultative methylotrophs (PPFMs) (Dourado et al. 2015) that are able to form endophytic associations with a range of plant species including citrus (Araújo et al. 2002), cotton (Madhaiyan et al. 2012), eucalyptus (Andreote et al. 2009), mangrove (Dourado et al. 2012), peanut (Madhaiyan et al. 2006b), pine (Pohjanen et al. 2014), tobacco (Andreote et al. 2006) and white cabbage (Wassermann et al. 2017). PPFMs are not pathogenic to their plant hosts (Idris et al. 2006) making them ideal candidates for endophytic biological control strategies (Omer et al. 2004). Additionally, Methylobacterium spp. are able to enhance plant growth through several mechanisms, including, nitrogen fixation (Lee et al. 2006; Menna et al. 2006; Sy et al. 2001), phytohormone production such as cytokinins and auxins (Madhaiyan et al. 2006a; Meena et al. 
320

321

322

323

324

325

326

327

328

329

330

331

332

333

334

335

336

337

338

339

340

341

342

343

344

345

346

347

348

349

350

351

352

353

354

355

356

357

358

359

2012; Trotsenko et al. 2001), interact with and inhibit plant pathogens (Araújo et al. 2002; Lacava et al. 2004; Poorniammal et al. 2009), promote plant growth (Madhaiyan et al. 2006a; Madhaiyan et al. 2006b; Tani et al. 2012), induce higher photosynthetic activity (CervantesMartínez et al. 2004), induce systemic resistance (Madhaiyan et al. 2006b), decrease environmental stress (Muller et al. 2011) and immobilize heavy metals (Dourado et al. 2012). We analyzed the fresh weight of seedlings of an oilseed rape cultivar under growth chamber condition when the roots were inoculated with two isolates of Methylobacterium fujisawaense and Methylobacterium phyllosphaerae and found that inoculated plants had a higher growth rate that non-inoculated plants. Cultivated Brassica crops such as oilseed rape, have a high nitrogen demand (Rathke et al. 2006) and their cultivation is reliant on fertilization with nitrogen rich products. These crops usually have low nitrogen use efficiency and this is a specific target for the breeding of new cultivars (Bouchet et al. 2016; Bouchet et al. 2014). The frequent presence of Methylobacterium in wild Brassica species, that are usually found within infertile soils, such as those where some of the wild species used in our study were collected suggests that this symbiosis improves the development of the host plant. These bacteria may therefore possess traits for use as plant growth promoters in artificial Brassica hosts such as domesticated cultivars.

This study isolated species of Methylobacterium, and the closely related Methylorubrum extorquens (Green \& Ardley 2018), from above and below ground plant organs (shoot and root, respectively). As morphologically similar isolates were identified from multiple root and shoot tissue pieces belonging to the same individual plant, we speculate that these bacterial isolates are capable of systemic plant colonization. Additionally, these tissues were dissected from symptomless seedlings grown from surface disinfected seed under sterile conditions and therefore this strongly suggests that these bacteria are vertically transmitted. The Methylobacterium species isolated in this study were present in a range of plant accessions originating from a geographically diverse set of countries with varied altitude. This is consistent with other reports of endophytic microbes, for example, among Zea spp. which were found across species grown in wide range of geographical locations (Johnston-Monje \& Raizada 2011).

It has been reported the age of seed may considerably influence the seed microbiome (Cankar et al. 2005). Indeed, no bacteria were isolated from six accessions that had been stored for more than 15 years. However, one accession that was over 26 years old gave rise to Methylobacterium indicating that this bacterium can adapt and survive in seed tissues for a long period of storage time. Mano et al. (2006) reported that only certain bacteria such as Methylobacterium are able to reside inside rice seed. These endophytic bacteria enter the seeds during the seed maturation stages and are tolerant to high osmotic pressure. The isolates possess a high degree of amylase activity, which may aid survival in the seed (Mano et al. 2006).

\section{Conclusions}

Peer) reviewing PDF | (2020:02:46010:1:1:NEW 8 Jun 2020) 
360

361

362

363

364

365

366

367

368

369

370

371

372

373

374

375

376

377

378

379

380

381

382

383

384

385

386

387

388

389

390

391

392

393

394

395

396

397

398

399

400

401

Although three species of Methylobacterium, namely Methylobacterium extorquens, Methylobacterium mesophilicum and Methylobacterium goesingense, were previously identified in Thlaspi goesingense belonging to the wider Brassicaceae family (Idris et al. 2006), to our knowledge this is the first report to describe the isolation and identification of endophytic bacteria of seeds of wild and landrace Brassica species. We present a straight-forward strategy to screen and cultivate seed-originating endophytes with possible beneficial traits.

The microbiome of many vegetables, including Brassica spp., can serve as sources of biological control agents (Wassermann et al. 2017) while focusing our efforts on seed-originating organisms may facilitate novel endophyte technologies that could be incorporated into future crop seed (Berg et al. 2017). This approach would then also be advantageous to companies that wish to invest in the commercialization of such products as they can lower their financial risk in terms of delivering a suitable efficacious product to farmers whilst protecting their IP. The latter is possible because an elite plant cultivar and the biological control agent can be protected together in one commercial seed product entity. This means of propagation relies on the plant's reproductive strategy and may aid the marketing of any potential plant-endophyte product (Card et al. 2016).

\section{Acknowledgements}

We would like to express our appreciation to Jaspreet Singh and Anouck de Bonth (both from AgResearch Limited) and Jana Monk (AsureQuality Limited, New Zealand) for their technical support. We thank Eirian Jones (Lincoln University, New Zealand) for kindly supplying the culture of Leptosphaeria maculans and DSV seeds for providing oilseed rape, cv. King.

\section{References}

Adams P, and Kloepper J. 1996. Seed-borne bacterial endophytes in different cotton cultivars. Phytopathology 86:S97.

Ali H, Ali Z, Ali H, Mehmood S, and Ali W. 2007. In vitro regeneration of Brassica napus L., cultivars (Star, Cyclone and Westar) from hypocotyls and cotyledonary leaves. Pakistan Journal of Botany 39:1251.

Aly AH, Debbab A, and Proksch P. 2011. Fungal endophytes: unique plant inhabitants with great promises. Applied microbiology and biotechnology 90:1829-1845.

Andreote FD, Carneiro RT, Salles JF, Marcon J, Labate CA, Azevedo JL, and Araújo WL. 2009. Culture-independent assessment of Rhizobiales-related Alphaproteobacteria and the diversity of Methylobacterium in the rhizosphere and rhizoplane of transgenic eucalyptus. Microbial Ecology 57:82-93.

Andreote FD, Lacava PT, Gai CS, Araújo WL, Maccheroni J, Walter, van Overbeek LS, van Elsas JD, and Azevedo JL. 2006. Model plants for studying the interaction between Methylobacterium mesophilicum and Xylella fastidiosa. Canadian Journal of Microbiology 52:419-426.

Araújo WL, Marcon J, Maccheroni W, van Elsas JD, van Vuurde JW, and Azevedo JL. 2002. Diversity of endophytic bacterial populations and their interaction with Xylella fastidiosa in citrus plants. Applied and Environmental Microbiology 68:4906-4914. 
402

403

404

405

406

407

408

409

410

411

412

413

414

415

416

417

418

419

420

421

422

423

424

425

426

427

428

429

430

431

432

433

434

435

436

437

438

439

440

441

442

443

444

445

Azevedo JL, Maccheroni Jr W, Pereira JO, and de Araújo WL. 2000. Endophytic microorganisms: a review on insect control and recent advances on tropical plants. Electronic Journal of Biotechnology 3:15-16.

Bent E, and Chanway CP. 2002. Potential for misidentification of a spore-forming Paenibacillus polymyxa isolate as an endophyte by using culture-based methods. Applied and Environmental Microbiology 68:4650-4652.

Berg G, and Hallmann J. 2006. Control of plant pathogenic fungi with bacterial endophytes. Microbial Root Endophytes: Springer, 53-69.

Berg G, Köberl M, Rybakova D, Müller H, Grosch R, and Smalla K. 2017. Plant microbial diversity is suggested as the key to future biocontrol and health trends. FEMS Microbiology Ecology 93. 10.1093/femsec/fix050

Bouchet A-S, Laperche A, Bissuel-Belaygue C, Snowdon R, Nesi N, and Stahl A. 2016. Nitrogen use efficiency in rapeseed. A review. Agronomy for Sustainable Development $36: 38$.

Bouchet A-S, Nesi N, Bissuel C, Bregeon M, Lariepe A, Navier H, Ribiere N, Orsel M, GrezesBesset B, and Renard M. 2014. Genetic control of yield and yield components in winter oilseed rape (Brassica napus L.) grown under nitrogen limitation. Euphytica 199:183205.

Cankar K, Kraigher H, Ravnikar M, and Rupnik M. 2005. Bacterial endophytes from seeds of Norway spruce (Picea abies L. Karst). FEMS Microbiology Letters 244:341-345.

Card S, Johnson L, Teasdale S, and Caradus J. 2016. Deciphering endophyte behaviour: the link between endophyte biology and efficacious biological control agents. FEMS Microbiology Ecology 92.

Card SD, Hume DE, Roodi D, McGill CR, Millner JP, and Johnson RD. 2015. Beneficial endophytic microorganisms of Brassica-A review. Biological Control 90:102-112.

Cervantes-Martinez J, López-Díaz S, and Rodríguez-Garay Bn. 2004. Detection of the effects of Methylobacterium in Agave tequilana Weber var. azul by laser-induced fluorescence. Plant science 166:889-892.

Dixon GR. 2007. Vegetable brassicas and related crucifers. Reading: CABI.

Dourado MN, Aparecida Camargo Neves A, Santos DS, and Araújo WL. 2015. Biotechnological and agronomic potential of endophytic pink-pigmented methylotrophic Methylobacterium spp. BioMed research international 2015.

Dourado MN, Ferreira A, Araújo WL, Azevedo JL, and Lacava PT. 2012. The diversity of endophytic methylotrophic bacteria in an oil-contaminated and an oil-free mangrove ecosystem and their tolerance to heavy metals. Biotechnology research international 2012.

Elbeltagy A, Nishioka K, Suzuki H, Sato T, Sato Y-I, Morisaki H, Mitsui H, and Minamisawa K. 2000. Isolation and characterization of endophytic bacteria from wild and traditionally cultivated rice varieties. Soil Science and Plant Nutrition 46:617-629.

Ferreira A, Quecine MC, Lacava PT, Oda S, Azevedo JL, and Araújo WL. 2008. Diversity of endophytic bacteria from Eucalyptus species seeds and colonization of seedlings by Pantoea agglomerans. FEMS Microbiology Letters 287:8-14.

Fisher P, and Petrini O. 1992. Fungal saprobes and pathogens as endophytes of rice (Oryza sativa L.). New Phytologist 120:137-143.

Peer] reviewing PDF | (2020:02:46010:1:1:NEW 8 Jun 2020) 
446 Germida JJ, Siciliano SD, De Freitas JR, and Seib AM. 1998. Diversity of root-associated

447

448

449

450

451

452

453

454

455

456

457

458

459

460

461

462

463

464

465

466

467

468

469

470

471

472

473

474

475

476

477

478

479

480

481

482

483

484

485

486

487

488

489

490 bacteria associated with field-grown canola (Brassica napus L.) and wheat (Triticum aestivum L.). FEMS Microbiology Ecology 26:43-50. 10.1016/s0168-6496(98)00020-8

Gómez-Campo C. 1980. Morphology and morpho-taxonomy of the tribe Brassiceae. In: Tsunoda S, Hinata K, and Gomez-Campo C, eds. Brassica crops and wild allies Biology and breeding. Tokyo, Japan: Japan Scientific Societies Press, 3-31.

Granér G, Persson P, Meijer J, and Alström S. 2003. A study on microbial diversity in different cultivars of Brassica napus in relation to its wilt pathogen, Verticillium longisporum. FEMS Microbiology Letters 224:269-276. 10.1016/s0378-1097(03)00449-x

Green PN, and Ardley JK. 2018. Review of the genus Methylobacterium and closely related organisms: a proposal that some Methylobacterium species be reclassified into a new genus, Methylorubrum gen. nov. International journal of systematic and evolutionary microbiology 68:2727-2748. https://doi.org/10.1099/ijsem.0.002856

Hallmann J, Quadt-Hallmann A, Mahaffee WF, and Kloepper JW. 1997. Bacterial endophytes in agricultural crops. Canadian Journal of Microbiology 43:895-914.

Hammoudi O, Salman M, Abuamsha R, and Ehlers R-U. 2012. Effectiveness of bacterial and fungal isolates to control Phoma lingam on oilseed rape Brassica napus. American Journal of Plant Sciences 3:773.

Hardoim PR, van Overbeek LS, Berg G, Pirttilä AM, Compant S, Campisano A, Döring M, and Sessitsch A. 2015. The hidden world within plants: ecological and evolutionary considerations for defining functioning of microbial endophytes. Microbiology and Molecular Biology Reviews 79:293. 10.1128/MMBR.00050-14

Harman G. 1983. Mechanisms of seed infection and pathogenesis. Phytopathology 73:326-328. Idris R, Kuffner M, Bodrossy L, Puschenreiter M, Monchy S, Wenzel WW, and Sessitsch A. 2006. Characterization of Ni-tolerant methylobacteria associated with the hyperaccumulating plant Thlaspi goesingense and description of Methylobacterium goesingense sp. nov. Systematic and Applied Microbiology 29:634-644. http://dx.doi.org/10.1016/j.syapm.2006.01.011

Johnston-Monje D, and Raizada MN. 2011. Conservation and diversity of seed associated endophytes in Zea across boundaries of evolution, ethnography and ecology. PLoS ONE 6:e20396.

Katoh K, and Standley DM. 2013. MAFFT Multiple sequence alignment software version 7: improvements in performance and usability. Molecular Biology and Evolution 30:772780.

Khalaf EM, and Raizada MN. 2016. Taxonomic and functional diversity of cultured seed associated microbes of the cucurbit family. BMC microbiology 16:131.

Khan AL, Waqas M, Kang S-M, Al-Harrasi A, Hussain J, Al-Rawahi A, Al-Khiziri S, Ullah I, Ali L, and Jung H-Y. 2014. Bacterial endophyte Sphingomonas sp. LK11 produces gibberellins and IAA and promotes tomato plant growth. Journal of Microbiology 52:689-695.

Kimber D, and McGregor D. 1995. Brassica oilseeds: production and utilization. Wallingford, UK: CAB International.

Kumar S, Stecher G, Li M, Knyaz C, and Tamura K. 2018. MEGA X: Molecular evolutionary genetics analysis across computing platforms. Molecular Biology and Evolution 35:15471549. 
491

492

493

494

495

496

497

498

499

500

501

502

503

504

505

506

507

508

509

510

511

512

513

514

515

516

517

518

519

520

521

522

523

524

525

526

527

528

529

530

531

532

533

534

535
Lacava P, Araújo WL, Marcon J, Maccheroni Jr W, and Azevedo JLd. 2004. Interaction between endophytic bacteria from citrus plants and the phytopathogenic bacteria Xylella fastidiosa, causal agent of citrus-variegated chlorosis. Letters in Applied Microbiology 39:55-59.

Lee HS, Madhaiyan M, Kim CW, Choi SJ, Chung KY, and Sa TM. 2006. Physiological enhancement of early growth of rice seedlings (Oryza sativa L.) by production of phytohormone of $\mathrm{N}_{2}$-fixing methylotrophic isolates. Biology and fertility of soils 42:402408.

Lob S. 2014. Leptosphaeria diseases of oilseed rape and swede: identification and epidemiology $\mathrm{PhD}$. Lincoln University.

López-López A, Rogel MA, Ormeno-Orrillo E, Martínez-Romero J, and Martínez-Romero E. 2010. Phaseolus vulgaris seed-borne endophytic community with novel bacterial species such as Rhizobium endophyticum sp. nov. Systematic and Applied Microbiology 33:322327.

Madhaiyan M, Poonguzhali S, Ryu J, and Sa T. 2006a. Regulation of ethylene levels in canola (Brassica campestris) by 1-aminocyclopropane-1-carboxylate deaminase-containing Methylobacterium fujisawaense. Planta 224:268-278.

Madhaiyan M, Poonguzhali S, Senthilkumar M, Lee J-S, and Lee K-C. 2012. Methylobacterium gossipiicola sp. nov., a pink-pigmented, facultatively methylotrophic bacterium isolated from the cotton phyllosphere. International journal of systematic and evolutionary microbiology 62:162-167.

Madhaiyan M, Reddy BS, Anandham R, Senthilkumar M, Poonguzhali S, Sundaram S, and Sa T. 2006b. Plant growth-promoting Methylobacterium induces defense responses in groundnut (Arachis hypogaea L.) compared with rot pathogens. Current Microbiology 53:270-276.

Mano H, Tanaka F, Watanabe A, Kaga H, Okunishi S, and Morisaki H. 2006. Culturable surface and endophytic bacterial flora of the maturing seeds of rice plants (Oryza sativa) cultivated in a paddy field. Microbes and Environments 21:86-100.

Mastretta C, Barac T, Vangronsveld J, Newman L, Taghavi S, and Lelie Dvd. 2006. Endophytic bacteria and their potential application to improve the phytoremediation of contaminated environments. Biotechnology and genetic engineering reviews 23:175-188.

Mastretta C, Taghavi S, Van Der Lelie D, Mengoni A, Galardi F, Gonnelli C, Barac T, Boulet J, Weyens N, and Vangronsveld J. 2009. Endophytic bacteria from seeds of Nicotiana tabacum can reduce cadmium phytotoxicity. International Journal of Phytoremediation 11:251-267.

Meena KK, Kumar M, Kalyuzhnaya MG, Yandigeri MS, Singh DP, Saxena AK, and Arora DK. 2012. Epiphytic pink-pigmented methylotrophic bacteria enhance germination and seedling growth of wheat (Triticum aestivum) by producing phytohormone. Antonie van Leeuwenhoek 101:777-786.

Menna P, Hungria M, Barcellos FG, Bangel EV, Hess PN, and Martínez-Romero E. 2006. Molecular phylogeny based on the 16S rRNA gene of elite rhizobial strains used in Brazilian commercial inoculants. Systematic and Applied Microbiology 29:315-332.

Mousa WK, Shearer CR, Limay-Rios V, Zhou T, and Raizada MN. 2015. Bacterial endophytes from wild maize suppress Fusarium graminearum in modern maize and inhibit mycotoxin accumulation. Frontiers in plant science 6:805.

Peer) reviewing PDF | (2020:02:46010:1:1:NEW 8 Jun 2020) 
536 Muller EE, Hourcade E, Louhichi-Jelail Y, Hammann P, Vuilleumier S, and Bringel F. 2011.

537

538

539

540

541

542

543

544

545

546

547

548

549

550

551

552

553

554

555

556

557

558

559

560

561

562

563

564

565

566

567

568

569

570

571

572

573

574

575

576

577

578

579

580

581
Functional genomics of dichloromethane utilization in Methylobacterium extorquens DM4. Environmental microbiology 13:2518-2535.

Mundt JO, and Hinkle NF. 1976. Bacteria within ovules and seeds. Applied and Environmental Microbiology 32:694-698.

Murashige T, and Skoog F. 1962. A revised medium for rapid growth and bioassays with tobacco tissue cultures. Physiologia Plantarum 15:473-497.

Narisawa K, Tokumasu S, and Hashiba T. 1998. Suppression of clubroot formation in Chinese cabbage by the root endophytic fungus, Heteroconium chaetospira. Plant Pathology 47:206-210.

Neergaard P. 2011. Seed Pathology: Volumes 1 and 2: Macmillan International Higher Education.

Okunishi S, Sako K, Mano H, Imamura A, and Morisaki H. 2005. Bacterial flora of endophytes in the maturing seed of cultivated rice (Oryza sativa). Microbes and Environments 20:168-177.

Pohjanen J, Koskimäki JJ, Sutela S, Ardanov P, Suorsa M, Niemi K, Sarjala T, Häggman H, and Pirttilä AM. 2014. Interaction with ectomycorrhizal fungi and endophytic Methylobacterium affects nutrient uptake and growth of pine seedlings in vitro. Tree physiology 34:993-1005.

Poorniammal R, Sundaram S, and Kumutha K. 2009. In vitro biocontrol activity of Methylobacterium extorquens against fungal pathogens. International Journal of Plant Protection 2:59-62.

Porras-Alfaro A, and Bayman P. 2011. Hidden fungi, emergent properties: endophytes and microbiomes. Annual review of phytopathology 49:291-315.

Putra IP, Rahayu G, and Hidayat I. 2015. Impact of domestication on the endophytic fungal diversity associated with wild Zingiberaceae at Mount Halimun Salak National Park. HAYATI Journal of Biosciences 22:157-162.

Rakow G. 2004. Species origin and economic importance of Brassica. In: Pua EC, and Douglas CJ, eds. Brassica Biotechnology in Agriculture and Forestry, vol 54. Berlin: SpringerVerlag, 3-11.

Rashid S, Charles TC, and Glick BR. 2012. Isolation and characterization of new plant growthpromoting bacterial endophytes. Applied soil ecology 61:217-224.

Rathke G-W, Behrens T, and Diepenbrock W. 2006. Integrated nitrogen management strategies to improve seed yield, oil content and nitrogen efficiency of winter oilseed rape (Brassica napus L.): a review. Agriculture, ecosystems \& environment 117:80-108.

Rijavec T, Lapanje A, Dermastia M, and Rupnik M. 2007. Isolation of bacterial endophytes from germinated maize kernels. Canadian Journal of Microbiology 53:802-808.

Rodriguez RJ, White Jr JF, Arnold AE, and Redman RS. 2009. Fungal endophytes: diversity and functional roles. New Phytologist 182:314-330. 10.1111/j.1469-8137.2009.02773.x

Rout ME, and Chrzanowski TH. 2009. The invasive Sorghum halepense harbors endophytic $\mathrm{N}_{2}-$ fixing bacteria and alters soil biogeochemistry. Plant and Soil 315:163-172.

Rybakova D, Mancinelli R, Wikström M, Birch-Jensen A-S, Postma J, Ehlers R-U, Goertz S, and Berg G. 2017. The structure of the Brassica napus seed microbiome is cultivardependent and affects the interactions of symbionts and pathogens. Microbiome 5:104.

Sanger F, and Coulson AR. 1975. A rapid method for determining sequences in DNA by primed synthesis with DNA polymerase. Journal of molecular biology 94:441-448. 
582

583

584

585

586

587

588

589

590

591

592

593

594

595

596

597

598

599

600

601

602

603

604

605

606

607

608

609

610

611

612

613

614
Sessitsch A, Reiter B, and Berg G. 2004. Endophytic bacterial communities of field-grown potato plants and their plant-growth-promoting and antagonistic abilities. Canadian Journal of Microbiology 50:239-249.

Sheng XF, Xia JJ, Jiang CY, He LY, and Qian M. 2008. Characterization of heavy metalresistant endophytic bacteria from rape (Brassica napus) roots and their potential in promoting the growth and lead accumulation of rape. Environmental Pollution 156:11641170. 10.1016/j.envpol.2008.04.007

Sunkar S, and Nachiyar CV. 2013. Isolation and characterization of an endophytic bacterium from Brassica oleracea with potential enzyme and antibacterial activity. Asian Journal of Pharmaceutical and Clinical Research 6:183-187.

Sy A, Giraud E, Jourand P, Garcia N, Willems A, De Lajudie P, Prin Y, Neyra M, Gillis M, and Boivin-Masson C. 2001. Methylotrophic Methylobacterium bacteria nodulate and fix nitrogen in symbiosis with legumes. Journal of bacteriology 183:214-220.

Tani A, Takai Y, Suzukawa I, Akita M, Murase H, and Kimbara K. 2012. Practical application of methanol-mediated mutualistic symbiosis between Methylobacterium species and a roof greening moss, Racomitrium japonicum. PLoS ONE 7:e33800.

Trotsenko YA, Ivanova E, and Doronina N. 2001. Aerobic methylotrophic bacteria as phytosymbionts. Microbiology 70:623-632.

Vega FE, Pava-Ripoll M, Posada F, and Buyer JS. 2005. Endophytic bacteria in Coffea arabica L. Journal of Basic Microbiology 45:371-380.

Wassermann B, Rybakova D, Müller C, and Berg G. 2017. Harnessing the microbiomes of Brassica vegetables for health issues. Scientific Reports 7:17649. 10.1038/s41598-01717949-z

Weisburg WG, Barns SM, Pelletier DA, and Lane DJ. 1991. 16S ribosomal DNA amplification for phylogenetic study. Journal of bacteriology 173:697-703.

Wilson D. 1995. Endophyte: the evolution of a term, and clarification of its use and definition. Oikos:274-276.

Ying W, Yang C-d, Yao Y-1, Wang Y-q, Zhang Z-f, and Li X. 2016. The diversity and potential function of endophytic bacteria isolated from Kobreasia capillifolia at alpine grasslands on the Tibetan Plateau, China. Journal of integrative agriculture 15:2153-2162.

Zhang Q, Zhang J, Yang L, Zhang L, Jiang D, Chen W, and Li G. 2014. Diversity and biocontrol potential of endophytic fungi in Brassica napus. Biological Control 72:98-108. 


\section{Table $\mathbf{1}$ (on next page)}

Seed-originating bacterial endophytes isolated from wild and landrace Brassica accessions. 


\begin{tabular}{|c|c|c|}
\hline Closest relative & Host species & Host origins \\
\hline $\begin{array}{l}\text { Methylobacterium } \\
\text { fujisawaense }\end{array}$ & $\begin{array}{l}\text { Brassica barrelieri, Brassica elongate, Brassica juncea, } \\
\text { Brassica nigra, Brassica rapa, Brassica napus, Brassica } \\
\text { sp. }\end{array}$ & $\begin{array}{l}\text { Iceland, India, Iran, Italy, New Zealand, } \\
\text { Portugal, Spain, Slovakia, Sweden, Sweden, } \\
\text { USA, Zambia }\end{array}$ \\
\hline $\begin{array}{l}\text { Methylobacterium } \\
\text { oryzae }\end{array}$ & Brassica barrelieri & Portugal \\
\hline $\begin{array}{l}\text { Methylobacterium } \\
\text { phyllosphaerae }\end{array}$ & Brassica incana, Brassica gravinae, Brassica napus & $\begin{array}{l}\text { Algeria, Finland, Iceland, New Zealand, } \\
\text { Norway, Sweden, Ukraine }\end{array}$ \\
\hline $\begin{array}{l}\text { Methylorubrum } \\
\text { extorquens }\end{array}$ & Brassica rapa & USA \\
\hline $\begin{array}{l}\text { Stenotrophomonas } \\
\text { rhizophila }\end{array}$ & Brassica juncea, Brassica oleracea & Germany, Slovakia, Thailand \\
\hline $\begin{array}{l}\text { Sphingomonas } \\
\text { paucimobilis }\end{array}$ & Brassica balearica & Unknown \\
\hline $\begin{array}{l}\text { Sphingomonas } \\
\text { yantingensis }\end{array}$ & Brassica juncea, Brassica sp. & New Zealand, Slovakia \\
\hline Sphingomonas insulae & Brassica sp. & New Zealand \\
\hline Pseudomonas lactis & $\begin{array}{l}\text { Brassica balearica, Brassica juncea, Brassica nigra, } \\
\text { Brassica oleracea }\end{array}$ & Bulgaria, Germany, Thailand \\
\hline $\begin{array}{l}\text { Sphingobium } \\
\text { yanoikuyae }\end{array}$ & Brassica nigra & Italy \\
\hline Bacillus mycoides & Brassica sp., Brassica juncea & New Zealand, Slovakia \\
\hline
\end{tabular}




\begin{tabular}{lll}
$\begin{array}{l}\text { Novosphingobium } \\
\text { clariflavum }\end{array}$ & Brassica rapa & Russia \\
Novosphingobium & Brassica rapa & \\
resinovorum & & Russia \\
Plantibacter flavus & Brassica juncea & \\
Paenibacillus hordei & Brassica sp. & Mongolia \\
Kocuria palustris & Brassica napus & New Zealand \\
Caulobacter mirabilis & Brassica napus & Iceland \\
Brevundimonas & Brassica rapa & Iceland \\
vesicularis & & USA \\
Micrococcus aloeverae & Brassica sp. & \\
\hline
\end{tabular}


Figure 1

Phylogenetic tree of bacteria isolated from wild and landrace Brassica accessions utilising the maximum likelihood method, based on 16S rDNA gene sequences of isolates. Bootstrap values were $>55 \%$. 


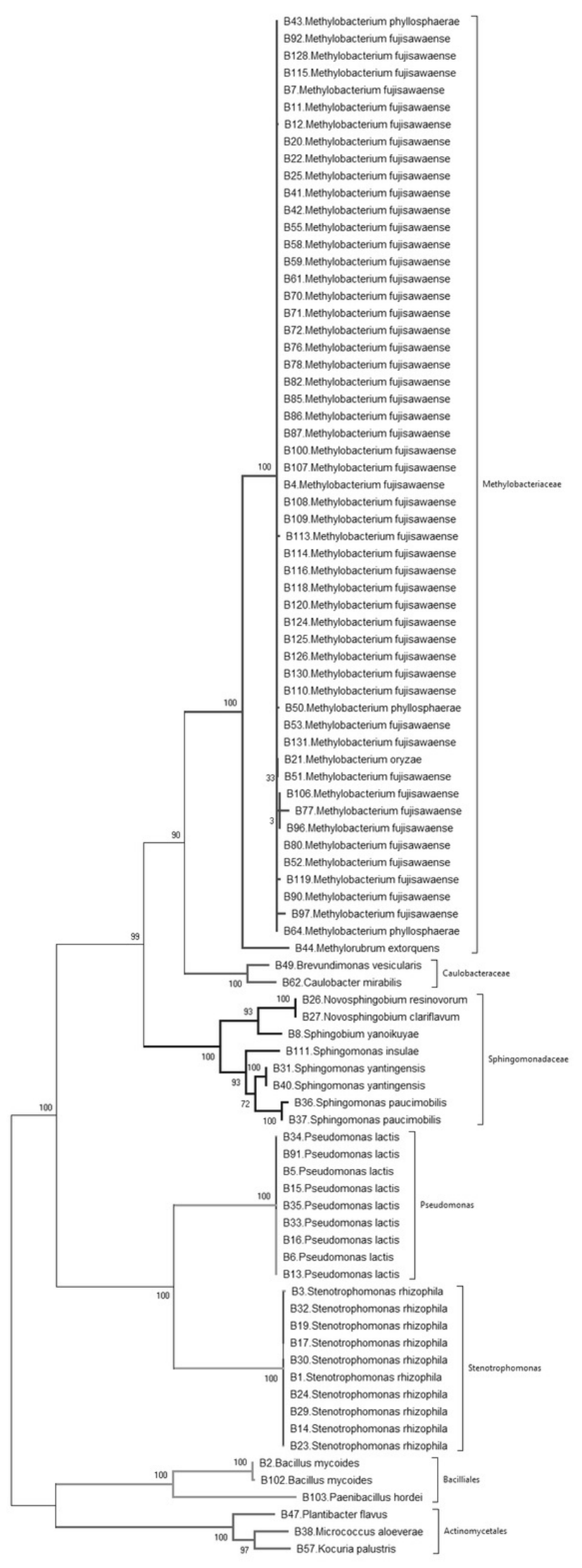


Figure 2

Mean dry weight of oilseed rape plants inoculated with Methylobacterium phyllosphaerae (B64) and Methylobacterium fujisawaense (B82) plus un-inoculated (control) plants ( \pm SD).

Bars followed by the same letter are not significantly $(P>0.05)$ different according to Fisher's protected LSD test.

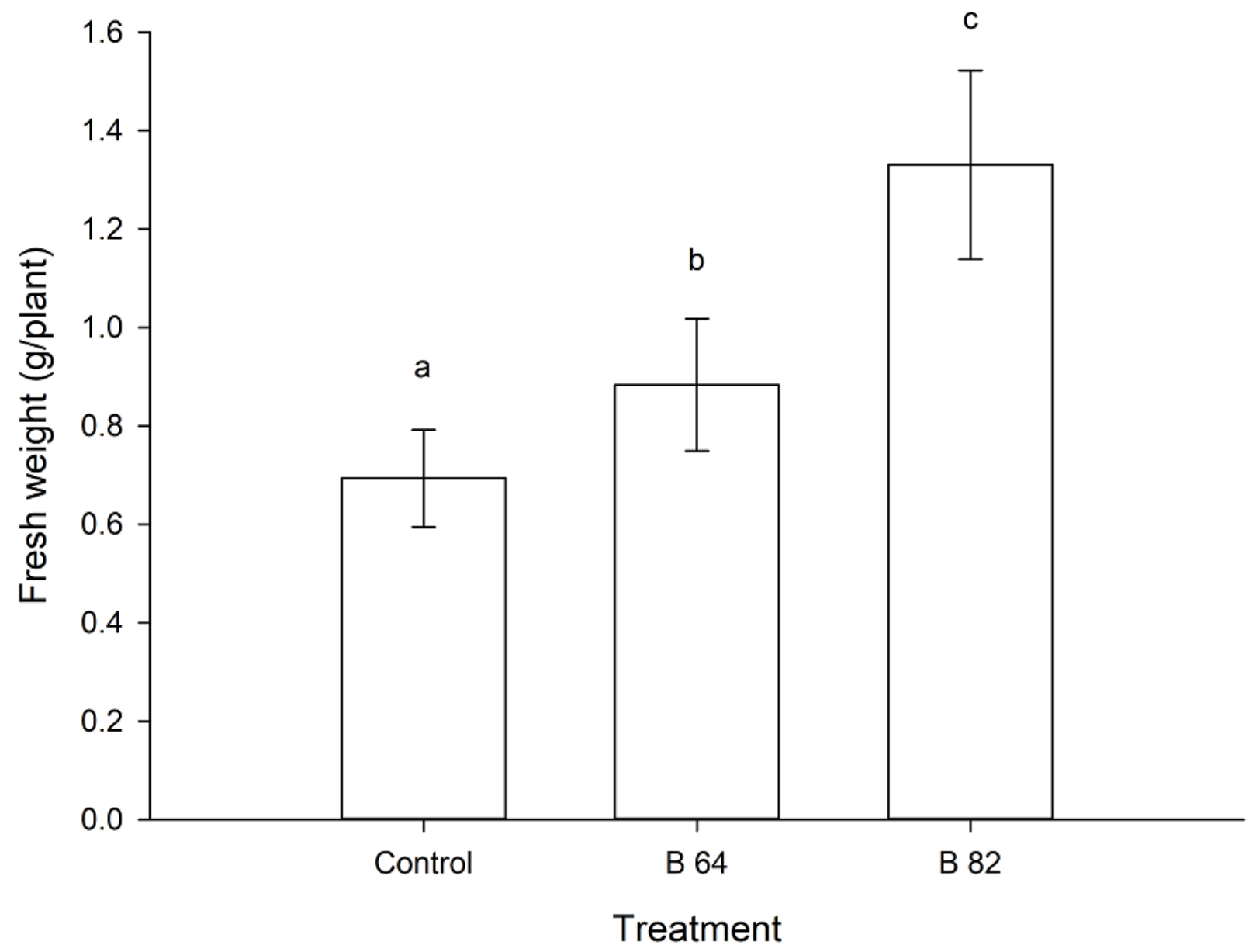

